This is needed to understand past and current behaviour of trees and to predict future responses to environmental stress.

My concern is that we don't know which parameters to model. In the absence of basic knowledge on stress physiology, modelling may merely provide interesting paradigms.
Let us hope it does not turn out to be like metaphysics: "a blind man, in a dark room, looking for a black cat, that isn't there'".

T.J. Blake

Faculty of Forestry University of Toronto

\title{
Publications of Interest
}

Strategic Plan 1991 to 1995. Forestry Canada, Newfoundland and Labrador Region. 1991. 14 pp.

Sour Felling in Alberta: Longer-Term Study. Patrick D. Forrester. 1991. Forest Engineering Research Institute of Canada, Tech. Note TN-164. 8 pp.

Short-Term Assessment of Three Powered-Disc Trencher/Prime Mover Options in Western Canada. Marc A. von der Gönna. 1991. Forest Engineering Research Institute of Canada, Tech. Note TN-165. $11 \mathrm{pp}$.

Evaluation of a Denis D3000 Telescopic Log Processor. Darcy W. Moshenko. 1991. Forest Engineering Research Institute of Canada, Tech. Note TN-166. 8 pp.

A Literature Synthesis on the Effects of Wood Quality in the Manufacture of Pulp and Paper. R. Pulkki. 1991. Forest Engineering Research Institute of Canada, Tech. Note TN-171. 8 pp.

Cable Yarding in Eastern Canada 5 Case Studies. J. Courteau and E. Heidersdorf. 1991. Forest Engineering Research Institute of Canada, Tech. Note TN-173. 16 pp.

Mulches Aid in Regenerating California and Oregon Forests: Past, Present, and Future. Philip M. McDonald and Ole T. Helgerson. 1990. U.S. Dept. Agriculture, Forest Service, Pacific Southwest Research Station, Gen. Tech. Rep. PSW-123. 19 pp.

Land-Use Planning May Reduce Fire Damage in the Urban-Wildland Intermix. Carol L. Rice and James B. Davis. 1991. U.S. Dept. Agriculture, Forest Service, Pacific Southwest Research Station, Gen. Tech. Rep. PSW-127. 13 pp.

Sixteenth Annual Report 1990-1991. The Algonquin Forestry Authority, 222 Main St. W., Box 1198, Huntsville, Ont. P0A 1K0.

Crop Planning Manual for Northern Ontario. J. Williams. 1991. Crop Planning Manual for Northern Ontario. Ministry of
Natural Resources, Northwestern Ontario Forest Technology Development Unit, Thunder Bay.

The Geography of the Canadian North. Issues and Challenges. R.M. Bone. Oxford University Press, 70 Wynford Drive, Don Mills, Ont. M3C 1J9. 256 pp. Price $\$ 19.95$.

Forest Pricing and Concession Policies. Managing the High Forests of West and Central Africa. 1991. Mikael Grut, John A. Gray and Nicolas Egli. World Bank Technical Paper Number 143, Africa Technical Department Series. 77 pp.

Spatial Processes in Plant Communities. F. Krahulec and others (Eds.), SPB Academic, The Hague, 259 p., 1990, US\$50.00.

Terrestrial Ecosystems. John D. Aber and Jerry M. Melillo, Saunders, Philadelphia, Pennsylvania, 430 p., 1991, US $\$ 37.25$ (paper).

Theoretical Studies of Ecosystems: The Network Perspective. M. Higashi and T.P. Burns (Eds.), Cambridge University Press, New York, 364 p., 1991, US\$75.00.

Comparative Analyses of Ecosystems: Patterns, Mechanisms, and Theories. Jonathon Cole, Gary Lovett, and Stuart Findlay (Eds.), 375 p., 1991, SpringerVerlag, New York, US\$79.00.

A Natural History of Trees of Eastern and Central North America. Donald Culross Peattie, illustrations by Paul Lanacre. Houghton Mifflin, Boston, 606 p., 1991, US\$16.95 (paper, reprint of 1948 edition).

A Natural History of Western Trees. Donald Culross Peattie, illustrations by Paul Lanacre. Houghton Mifflin, Boston, 751 p., 1991 , US $\$ 18.95$ (paper, reprint of 1950 edition).

Properties and Uses of New Zealand Radiata Pine. J.A. Kininmonth and L.J. Whitehouse, New Zealand Ministry of Forestry, Forest Research Institute, Private
Bag 3020, Rotorua, New Zealand, 238 p., $1991, \mathrm{NZ} \$ 60.00+\$ 14.00$ postage and handling to North America, ISBN 0-47301181-6.

Radiata Pine Wood Properties Survey revised ed. D.J. Cown, D.L. McConchie, and G.D. Young, New Zealand Ministry of Forestry, Forest Research Institute, Private Bag 3020, Rotorua, New Zealand, FRI Bulletin No. 50,? p., 1991, NZ\$30.00+ $\$ 8.00$ postage and handling to North America, ISBN?.

The Silviculture of Trees Used in British Forestry. Peter S. Savill, Commonwealth Agricultural Bureaux (CAB) International, 845 North Park Avenue, Tucson, Arizona, 142 p., $1991, £ 15.00$ (US $\$ 28.50$ Americas only), ISBN 0-85198-739-7.

Forestry: A Multiple-Use Enterprise. Proceedings of the 13th Commonwealth Forestry Conference, Rotorua, New Zealand, 17-30 September 1989, published by the New Zealand Ministry of Forestry, Forest Research Institute, Private Bag 3020, Rotorua, New Zealand, 376 p., 1990 , NZ $\$ 40.00+\$ 20.00$ postage and handling to North America.

The Rainforests of West Africa: Ecology - Threats - Conservation. Claude Martin, Birkhauser Boston, Secaucus, New Jersey, 235 p., 1991, US\$39.80.

Wildlife, Forests, and Forestry: Principles of Managing Forests for Biological Diversity. Malcolm L. Hunter, Jr., illustrations by Diane Bowman, Prentice Hall, Englewood Cliffs, New Jersey, 379 p., 1990, US\$47.00.

Genetics and Breeding of Ornamental Species. J. Harding, F. Singh, and J.N.M. Mol, Kluwer Academic, Norwell, Massachusetts, 432 p., 1991, US\$145.00 hardcover ISBN 0-7923-1094-2, \$69.50 softcover ISBN 0-7923-1364-X.

Botany: An Introduction to Plant Biology. James D. Mauseth, Saunders, Philadelphia, Pennsylvania, 800 p., 1991, US\$53.25.

Poison Ivy, Poison Oak, Poison Sumac, and Their Relatives. Edward Frankel, illustrations by Anthony Salazar, Boxwood, Pacific Grove, California, 98 p., 1991, US\$9.95 papercover.

Forestry on the Hill - Special Issue Herbicides. Canadian Forestry Association, 1991-5. Edited by: Glen Blouin and Roxanne Comeau. 65 pages. The publication contains some 20 statements concerning the use of herbicides in forestry, which have been prepared by the forest industry, the chemical industry, governments and environmental associations. 